\title{
In situ methanolic solvent synthesis, spectroscopic and thermogravimetric characterizations of three new transition metal complexes of trimethoprim drug
}

\author{
Moamen S. Refat ${ }^{*}$, Jehan Y. Al-Humaidi' ${ }^{2}$ Mohamed Y. El-Sayed ${ }^{3,4}$, Reham F. Hassan ${ }^{5}$ \\ ${ }^{1}$ Department of Chemistry, College of Science, Taif University, P.O. Box 11099, Taif 21944, Saudi Arabia \\ ${ }^{2}$ Department of Chemistry, College of Science, Princess Nourah bint Abdulrahman University, Riyadh 11671, KSA \\ ${ }^{3}$ Chemistry Department, College of Science, Jouf University, P.O. Box: 2014, Sakaka, Saudi Arabia \\ ${ }^{4}$ Department of Chemistry, Faculty of Science, Zagazig University, Egypt \\ ${ }^{5}$ Department of Chemistry, Faculty of Science, Helwan University, Cairo, Egypt \\ Corresponding author: e-mail: msrefat@yahoo.com \& moamen@tu.edu.sa
}

\begin{abstract}
Trimethoprim drug (TMP) complexes of copper (II), cobalt (II), and nickel (II) were prepared and discussed by using elemental analysis (C, H, N analysis), magnetic, molar conductance, FTIR, Raman spectroscopy, electron spin resonance (ESR) and UV-vis spectroscopy analyses. TMP drug coordinated as a tridentate ligand towards the respected three metal ions through two nitrogen atoms of amino groups and nitrogen atom of pyrimidine ring which flanked between $-\mathrm{NH}_{2}$ groups, these assignments confirmed by spectroscopic, magnetic, ESR and thermogravimetric analyses with formulas $\left[\mathrm{Cu}(\mathrm{TMP})\left(\mathrm{H}_{2} \mathrm{O}\right)_{3}\right] \mathrm{Cl}_{2}$, $\left[\mathrm{Co}(\mathrm{TMP})\left(\mathrm{H}_{2} \mathrm{O}\right)_{3}\right] \mathrm{Cl}_{2}$ and $\left[\mathrm{Ni}(\mathrm{TMP})\left(\mathrm{H}_{2} \mathrm{O}\right)\right] \mathrm{Cl}_{2}$. Copper (II) and cobalt (II) complexes have an octahedral geometrical structure included one TMP molecule, three coordinated water molecules and two uncoordinated chlorine atoms while, nickel(II)-TMP complex has a tetrahedral geometric configuration that involved one TMP molecule, one coordinated water molecule and two uncoordinated chlorine atoms. The activation energies and other kinetic thermodynamic parameters were estimated based on the employed of the Coats-Redfern and Horowitz-Metzger equations. The nano-structured form of the synthesized TMP complexes was confirmed dependent on the transmission electron microscopy (TEM).
\end{abstract}

Keywords: Complexation; trimethoprim; transition metals; TGA; FTIR; ESR; kinetic thermodynamic parameters.

\section{INTRODUCTION}

The trimethoprim (TMP; Fig. 1) was classified as one an interesting anti-biotic and anti-parasitic drug${ }^{1}$. The TMP drug is distinguished as a good complexing agent towards different metal ions because it contains three nitrogen atoms on the pyrimidine ring ${ }^{2-4}$. Trimethoprim has potential binding sites for metal ions. Several authors have studied the interaction of this ligand with biological metal ions and the coordination of TMP via a $\mathrm{NH}_{2}$ nitrogen atom has been inferred based on IR and visible measurements ${ }^{5,6}$. However, other authors have shown by X-ray diffraction methods that the coordination site of the TMP molecule is the $\mathrm{N}_{1}$ of the pyrimidine $\operatorname{ring}^{7-14}$. On the other hand, other research group ${ }^{15-27}$ have prepared and characterized complexes of TMP with metal(II)/(III) and the spectral and analytical data show that the ligand acts as a monodentate or bidentate. Trimethoprim and isoniazid as a mixed ligand have been coordinated towards some of transition metal ions ${ }^{28}$. These resulted complexes have coordinated via nitrogen of pyrimidine ring and nitrogen atom of amino group of isoniazid ${ }^{28}$. Silver(I) complexes of mixed ligand of both trimethoprim and pyrimethamine were synthesized and well-characterized by analytical and spectroscopic analyses. The $\operatorname{Ag}(\mathrm{I})$ metal ion was coordinated with trimethoprim and pyrimethamine ligands through the nitrogen atoms of pyrimidine ring with three and four coordination behavior ${ }^{29}$. Silver(I) trimethoprim complexes were recorded a stronger antibacterial activity in comparison with free TMP drugs. Platinum (II) and Pd (II) complexes of TMP and pyrimethamine mixed ligands have a square planar geometry ${ }^{30}$. The $\mathrm{Cu}$ (II), $\mathrm{Zn}$ (II) and Ti(IV)-TMP complexes have been synthesized and spectroscopically characterized. These complexes have been shown a good antibacterial activity, besides this result, the $\mathrm{Ti}(\mathrm{IV})$ and $\mathrm{Cu}(\mathrm{II})$ complexes have excellent anticancer efficiency ${ }^{31}$. Mn (II), Fe (III), Co (II), Ni (II), $\mathrm{Cu}$ (II), $\mathrm{Zn}$ (II), $\mathrm{Pb}$ (II) and $\mathrm{La}$ (III) complexes of TMP derivative were prepared and the speculated structures were designed using a different physical and chemical tool of analyses. The geometry of these complexes confirmed that the TMP derivative ligand act as a bidentate chelate ${ }^{32}$. Herein, in this article, the 1:1 molar ratio of $\mathrm{Cu}$ (II), Co (II) and $\mathrm{Ni}$ (II)-TMP complexes were synthesized, spectroscopic and thermal analysis discussed.<smiles>COc1cc(Cc2cnc(N)nc2N)cc(OC)c1OC</smiles>

Figure 1. Structure of trimethoprim (TMP) drug

\section{EXPERIMENTAL}

\section{Chemicals}

Copper (II), cobalt (II) and nickel (II) chloride hydrate salts as well as trimethoprim drug were received from Sigma-Aldrich Chemical Company, USA and used in the preparation without further purification. 


\section{Instruments}

The type of analyses and their corresponding models can be listed as follows:

1. Elemental analyses; Conductance; FTIR spectra; Raman Spectroscopy; Thermogravimetric; Electronic spectra; Magnetic moment; XRD; ESR.

2. Models: Perkin Elmer CHN 2400; Jenway 4010 conductivity meter; Bruker FTIR Spectrophotometer; Bruker FT Raman with laser $50 \mathrm{~mW}$; TG/DTG-50H, Shimadzu thermogravimetric analyzer; UV2 Unicam UV/ Vis Spectrophotometer; Magnetic Susceptibility Balance; $\mathrm{X}$,Pert PRO PANanalytical, with copper target; Jeol, JES-FE2XG Spectrometer (Frequency $9.44 \mathrm{GHz}$ ).

\section{Synthesis}

Copper, cobalt and nickel (II) - trimethoprim complexes were prepared by mixing $1.0 \mathrm{mmol}$ of $\mathrm{CuCl}_{2} \cdot 2 \mathrm{H}_{2} \mathrm{O}$, $\mathrm{CoCl}_{2} \cdot 6 \mathrm{H}_{2} \mathrm{O}$ and $\mathrm{NiCl}_{2} \cdot 6 \mathrm{H}_{2} \mathrm{O}$ in $25 \mathrm{~mL}$ methanol with $1.0 \mathrm{mmol}$ TMP in $25 \mathrm{~mL}$ methanol. The mixtures were refluxed for $\sim 3$ hours till the colored precipitates appeared, the solid products were filtered off and washed several times with little amounts of methanol. The solid precipitates were dried and closed in a vacuum desiccator over anhydrous $\mathrm{CaCl}_{2}$.

\section{RESULTS AND DISCUSSIONS}

\section{Elemental analysis and conductance measurements}

The solid products of copper (II), cobalt (II) and nickel (II) - TMP complexes have a yield within the $72-76 \%$ range. The solubility of the synthesized complexes is soluble in DMSO and DMF organic solvents but insoluble in most organic solvents and water. The synthesized three $\mathrm{Cu}$ (II), Co (II) and $\mathrm{Ni}$ (II)-TMP complexes have a melting point at $315^{\circ} \mathrm{C}, 283^{\circ} \mathrm{C}$ and $260^{\circ} \mathrm{C}$ respectively, these sharp melting points of the solid complexes have supported the absence of any impurities. The elemental analysis $(\mathrm{C}, \mathrm{H}, \mathrm{N}$ and metal percentages) of the experimental results has a good matched with theoretical data as listed in Table 1 . The molar conductance of the $10^{-3} \mathrm{M}$ synthesized $\mathrm{Cu}(\mathrm{II})$, $\mathrm{Co}(\mathrm{II})$ and $\mathrm{Ni}(\mathrm{II})-\mathrm{TMP}$ complexes that dissolved in dimethyl sulfoxide (DMSO) solvent have $\Lambda_{\mathrm{m}}=76,81$, and $73 \mathrm{ohm}^{-1} \cdot \mathrm{cm}^{2} \cdot \mathrm{mol}^{-1}$ respectively. These results data confirmed that all three TMP complexes have an electrolytic property ${ }^{33}$. The appearance of various colored complexes confirmed the formation of new compositions. The speculated structures of the synthesized 1:1 (M:L) $\mathrm{Cu}(\mathrm{II}), \mathrm{Co}(\mathrm{II})$ and $\mathrm{Ni}(\mathrm{II})-\mathrm{TMP}$ complexes are shown in Fig. 2 with molecular formula $\left[\mathrm{Cu}(\mathrm{TMP})\left(\mathrm{H}_{2} \mathrm{O}\right)_{3}\right] \mathrm{Cl}_{2}$, $\left[\mathrm{Co}(\mathrm{TMP})\left(\mathrm{H}_{2} \mathrm{O}\right)_{3}\right] \mathrm{Cl}_{2}$ and $\left[\mathrm{Ni}(\mathrm{TMP})\left(\mathrm{H}_{2} \mathrm{O}\right)\right] \mathrm{Cl}_{2}$.

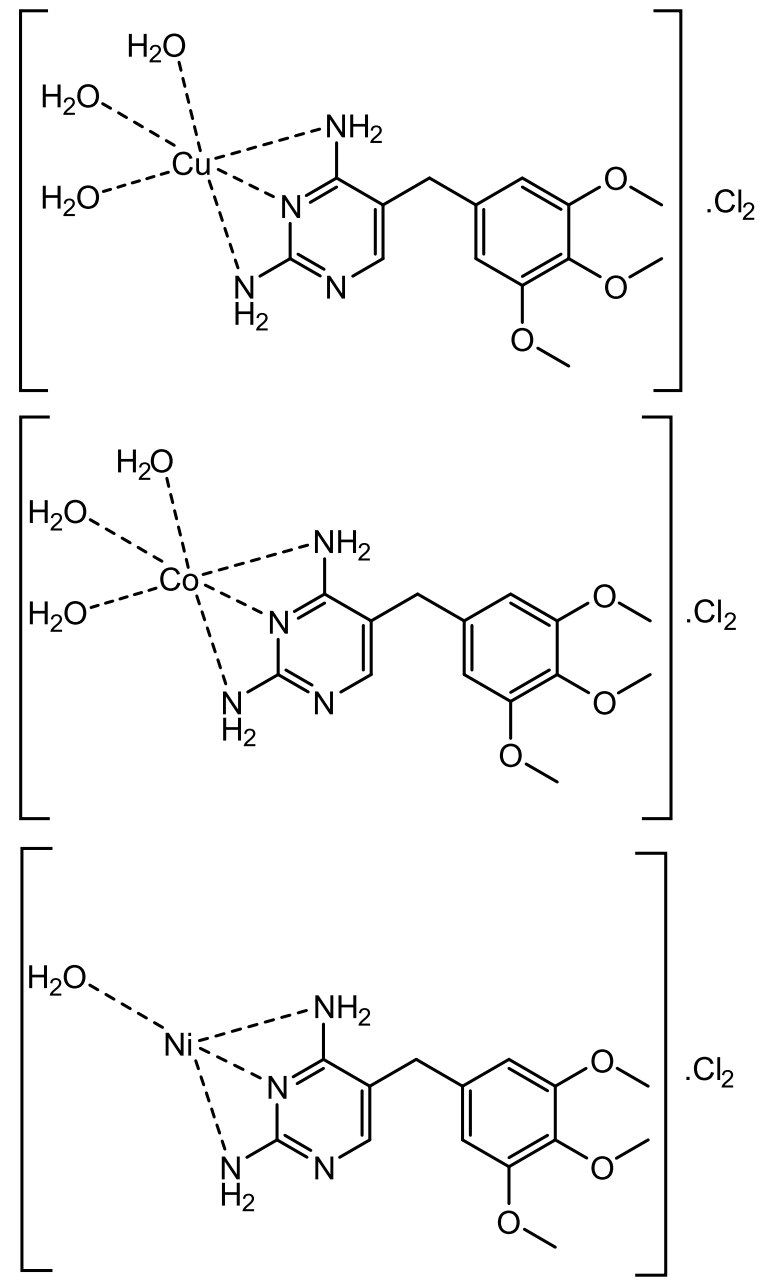

Figure 2. Suggested structures of the synthesized $\mathrm{Cu}(\mathrm{II}), \mathrm{Co}(\mathrm{II})$ and $\mathrm{Ni}(\mathrm{II})-\mathrm{TMP}$ complexes

\section{FTIR and Raman spectra}

Infrared spectra of the copper(II), cobalt(II) and nickel(II) complexes as well as trimethoprim free ligand are displayed in Fig. 3a, 3b, 3c, 3d and their assignments are tabulated in Table 2. The trimethoprim free ligand has an oxygen and nitrogen donating atoms through

Table 1. Elemental analysis and physical data of $\mathrm{Cu}^{2+}, \mathrm{Co}^{2+}$ and $\mathrm{Ni}^{2+}-\mathrm{TMP}$ complexes

\begin{tabular}{|c|c|c|c|c|c|}
\hline Complex & Color & $\begin{array}{c}\text { Conductance/ } \\
\left(\mathrm{ohm}^{-1} \cdot \mathrm{cm}^{2} \cdot \mathrm{mol}^{-1}\right)\end{array}$ & Element & Calc. $/ \%$ & Found $/ \%$ \\
\hline \multirow{5}{*}{$\mathrm{Cu}(\mathrm{II})$} & \multirow{5}{*}{ Greenish Brown } & \multirow[t]{5}{*}{ I } & C & 35.12 & 34.68 \\
\hline & & & $\mathrm{H}$ & 5.05 & 4.82 \\
\hline & & & $\mathrm{N}$ & 11.70 & 11.63 \\
\hline & & & $\mathrm{Cl}$ & 14.81 & 14.75 \\
\hline & & & $\mathrm{Cu}$ & 13.27 & 13.21 \\
\hline \multirow{5}{*}{$\mathrm{Co}(\mathrm{II})$} & \multirow{5}{*}{ Blue } & \multirow{5}{*}{81} & $\mathrm{C}$ & 35.46 & 35.45 \\
\hline & & & $\mathrm{H}$ & 5.10 & 4.62 \\
\hline & & & $\mathrm{N}$ & 11.81 & 11.54 \\
\hline & & & $\mathrm{Cl}$ & 14.95 & 14.91 \\
\hline & & & Co & 12.43 & 12.35 \\
\hline \multirow{5}{*}{$\mathrm{Ni}(\mathrm{II})$} & \multirow{5}{*}{ Green } & \multirow{5}{*}{73} & $\mathrm{C}$ & 38.40 & 38.31 \\
\hline & & & $\mathrm{H}$ & 4.60 & 4.39 \\
\hline & & & $\mathrm{N}$ & 12.79 & 12.60 \\
\hline & & & $\mathrm{Cl}$ & 16.19 & 16.14 \\
\hline & & & $\mathrm{Ni}$ & 13.40 & 13.34 \\
\hline
\end{tabular}


Table 2. Infrared spectral data $\left(\mathrm{cm}^{-1}\right)$ of TMP and its complexes

\begin{tabular}{|l|c|c|c|c|c|}
\hline \multirow{2}{*}{ Compounds } & \multicolumn{5}{|c|}{ Frequencies, $\mathrm{cm}^{-1}$} \\
\cline { 2 - 6 } & $\mathrm{v}_{\mathrm{as}}(\mathrm{NH})$ & $\mathrm{v}_{\mathrm{s}}(\mathrm{NH})$ & $\mathrm{v}(\mathrm{C}=\mathrm{N})$ & $\mathrm{v}(\mathrm{C}=\mathrm{C})$ & 1594 \\
\hline $\mathrm{TMP}$ & 3470 & 3319 & 1635 & $1 \mathrm{M}-\mathrm{N})$ \\
\hline $\mathrm{Cu}(\mathrm{II})$ & 3403 & 3306 & 1663 & 1591 & 514 \\
\hline $\mathrm{Co}(\mathrm{II})$ & 3404 & 3303 & 1674 & 1590 & 505 \\
\hline $\mathrm{Ni}(\mathrm{II})$ & 3404 & 3302 & 1674 & 1588 & 505 \\
\hline
\end{tabular}

pyrimidine nitrogen atoms $\left(-\mathrm{NH}_{2} \&-\mathrm{C}=\mathrm{N}\right.$ groups $)$ and oxygen of methoxyl groups. Trimethoprim free drug has a number of characteristic groups with stretching frequencies at $3470,3319,1635$ and $1594 \mathrm{~cm}^{-1}$ due to $v_{\mathrm{as}}\left(\mathrm{NH}_{2}\right), v_{\mathrm{s}}\left(\mathrm{NH}_{2}\right), v(\mathrm{C}=\mathrm{N}), v(\mathrm{C}=\mathrm{C})$ of pyrimidine and trimethoxy moieties. Regarding the vibration bands of $v_{\mathrm{as}}\left(\mathrm{NH}_{2}\right), v_{\mathrm{s}}\left(\mathrm{NH}_{2}\right)$ and $v(\mathrm{C}=\mathrm{N})$ of the pyrimidine ring are shifted to lower/higher wavenumbers after complexation and exhibited within the range of 3404-3403 $\mathrm{cm}^{-1}$, $3306-3302 \mathrm{~cm}^{-1}$ and $1674-1663 \mathrm{~cm}^{-1}$ respectively, this results supported the coordinated of nitrogen atoms of amino group and $-\mathrm{C}=\mathrm{N}$ towards central metal ions [2-4]. The new frequencies present in the spectra of complexes at $514-505 \mathrm{~cm}^{-1}$ region are attributed to $v(\mathrm{M}-\mathrm{N})$ and [3]. The infrared assignments confirmed that the TMP coordinated to respected metal ions as a tri-dentate ligand through the nitrogen atoms of the $-\mathrm{NH}_{2} \&-\mathrm{C}=\mathrm{N}$ groups for the pyrimidine ring. The Raman spectra (Fig. 4a, 4b, 4c) also agree with infrared spectra of the $\mathrm{Cu}(\mathrm{II}), \mathrm{Co}(\mathrm{II})$ and $\mathrm{Ni}(\mathrm{II})$ - TMP complexes. The presence of new frequency bands at around $\sim 430$ $\mathrm{cm}^{-1}$ in the case of the synthesized complexes are assigned to the $v(\mathrm{M}-\mathrm{N})$ vibration bands. In FTIR spectra of the prepared complexes, there are broad absorption bands of $(\mathrm{OH})$ with a maximum at $3174-3166 \mathrm{~cm}^{-1}$ and characteristic bands of bending to water hydrated, $\delta\left(\mathrm{H}_{2} \mathrm{O}\right)$ at $1645-1640 \mathrm{~cm}^{-1}$ confirming the presence of coordinated water molecules.

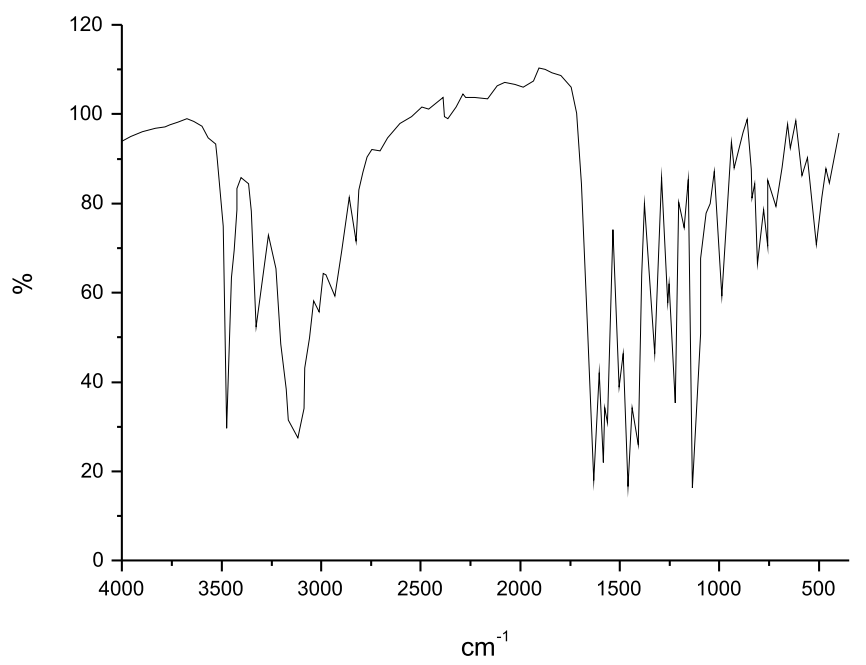

Figure 3a. FTIR spectrum of TMP

\section{Electronic spectra and magnetic susceptibility}

The electronic spectrum of copper(II)-TMP complex displays two distinguished bands. A low-intensity band at $19.608 \mathrm{~cm}^{-1}$ is assigned to ${ }^{2} \mathrm{Eg} \rightarrow{ }^{2} \mathrm{~T}_{2} \mathrm{~g}$ electronic transition and another low-intensity band at $23.923 \mathrm{~cm}^{-1}$ are due to symmetry forbidden $\mathrm{L} \rightarrow \mathrm{M}_{\mathrm{CT}}$. Based on the solid reflectance spectrum, the distorted octahedral geometry of $\left[\mathrm{Cu}(\mathrm{TMP})\left(\mathrm{H}_{2} \mathrm{O}\right)_{3}\right] \mathrm{Cl}_{2}$ is suggested ${ }^{34,35}$. The complex displays a higher magnetic moment value (1.88 $\mathrm{BM})$ than that of spin only moment $(1.73 \mathrm{BM})$. This can support the absence of any metal-metal interaction inside the crystal of the distorted geometry ${ }^{36}$. The [Co(TMP)

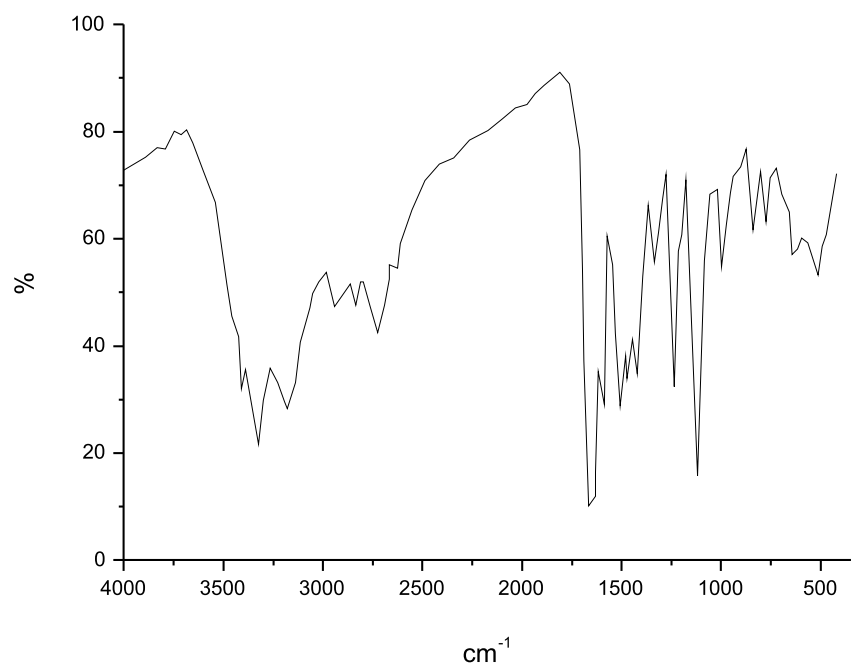

Figure 3b. Infrared spectrum of $\left[\mathrm{Cu}(\mathrm{TMP})\left(\mathrm{H}_{2} \mathrm{O}\right)_{3}\right] \mathrm{Cl}_{2}$ complex

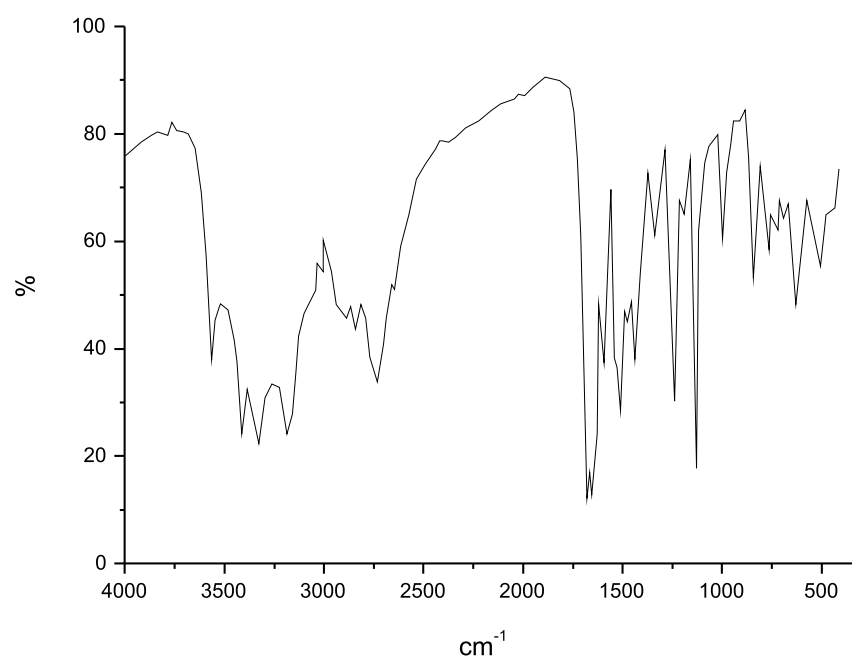

Figure 3c. Infrared spectrum of $\left[\mathrm{Co}(\mathrm{TMP})\left(\mathrm{H}_{2} \mathrm{O}\right)_{3}\right] \mathrm{Cl}_{2}$ complex

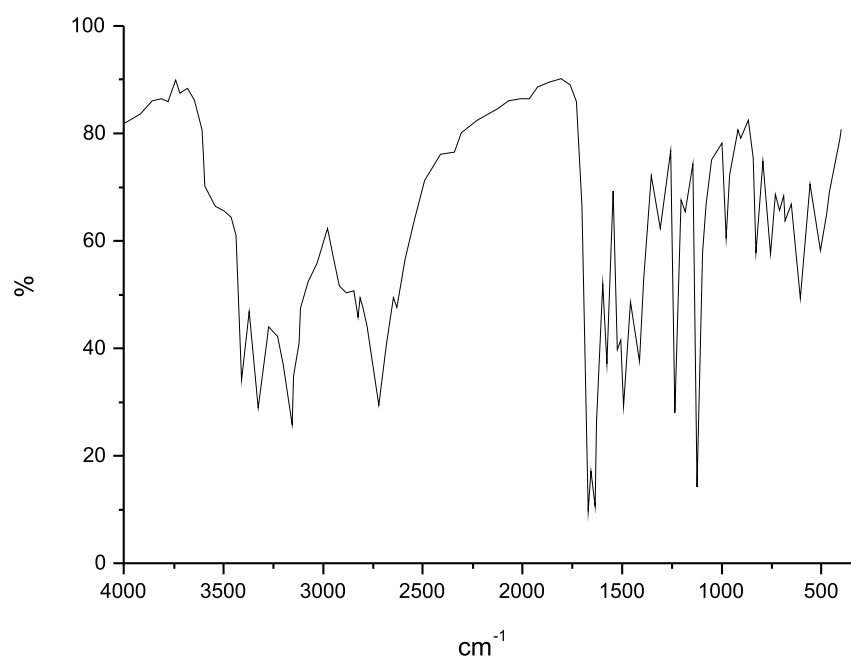

Figure 3d. The infrared spectrum of $\left[\mathrm{Ni}(\mathrm{TMP})\left(\mathrm{H}_{2} \mathrm{O}\right)\right] \mathrm{Cl}_{2}$ complex 


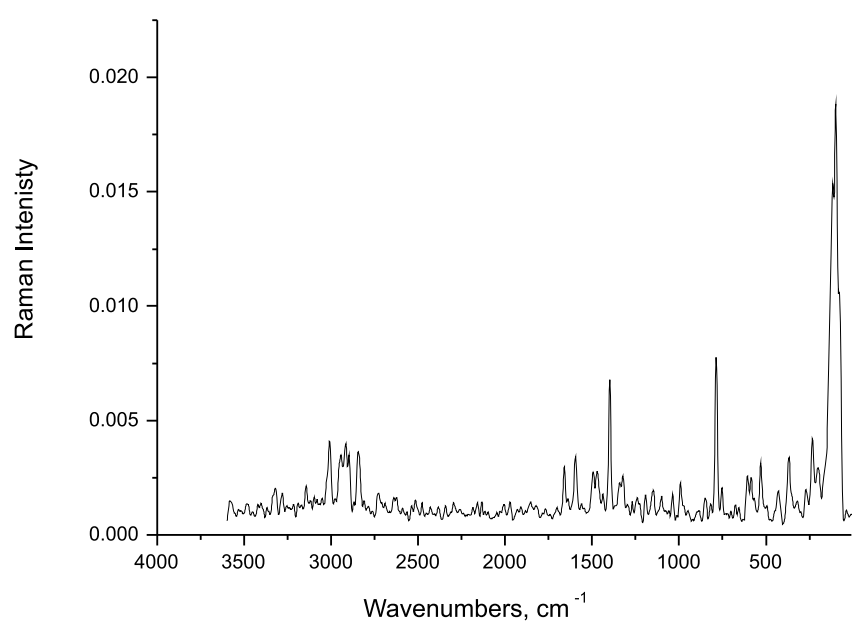

Figure 4a. Raman spectrum of TMP

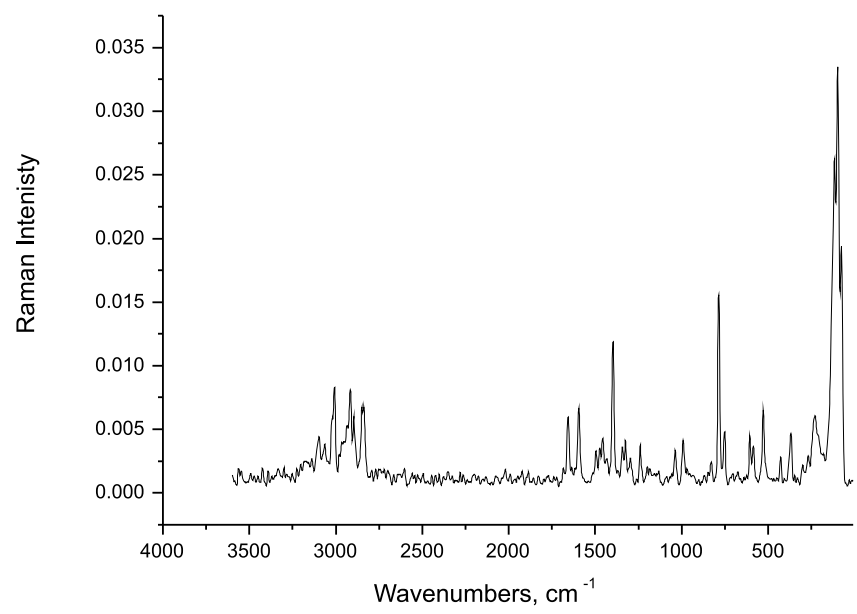

Figure 4b. Raman spectrum of Co(II)-TMP complex

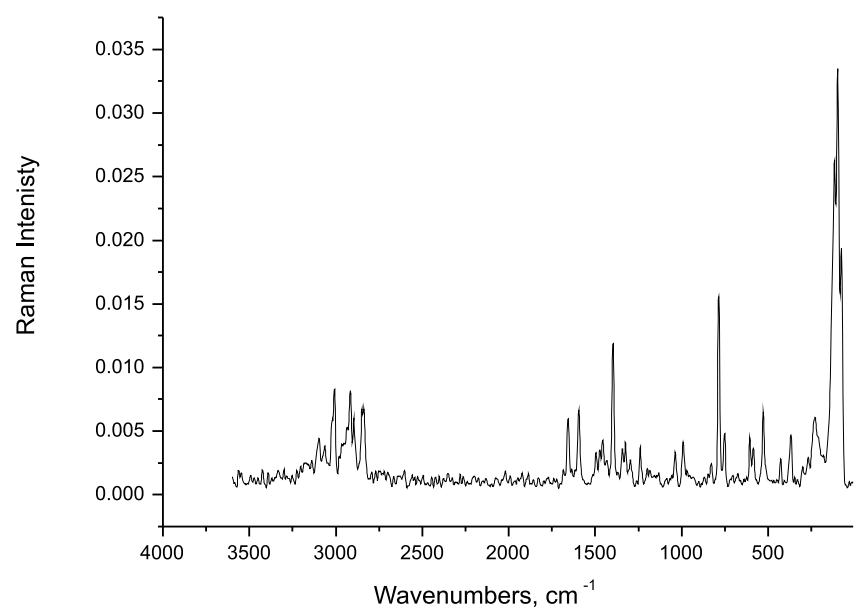

Figure 4c. Raman spectrum of Ni(II)-TMP complex

$\left.\left(\mathrm{H}_{2} \mathrm{O}\right)_{3}\right] \mathrm{Cl}_{2}$ complex shows a magnetic moment at 3.92 B.M. corresponding to three unpaired electrons. The electronic spectrum of the Co(II) complex displays three bands at 12.195, 15.649 and $24.570 \mathrm{~cm}^{-1}$. These bands are attributed to ${ }^{4} \mathrm{~T}_{1 \mathrm{~g}} \rightarrow{ }^{4} \mathrm{~T}_{2 \mathrm{~g}}(\mathrm{~F})(\mathrm{v} 1),{ }^{4} \mathrm{~T}_{1 \mathrm{~g}} \rightarrow{ }^{4} \mathrm{~A}_{2 \mathrm{~g}}(\mathrm{~F})(\mathrm{v} 2)$ and ${ }^{4} \mathrm{~T}_{1 \mathrm{~g}} \rightarrow{ }^{4} \mathrm{~T}_{1 \mathrm{~g}}(\mathrm{P})(\mathrm{v} 3)$ electronic transitions, respectively. The band assignments suggest an octahedral geometrical structure for the Co(II)-TMP complex ${ }^{37}$. The nickel(II) complex shows magnetic moment 2.90 B.M. corresponding to two unpaired electrons ${ }^{38}$. Electronic spectrum displays bands at $12.315,15.698$ and $21.052 \mathrm{~cm}^{-1}$. These bands may be assigned to ${ }^{3} \mathrm{~A}_{2}(\mathrm{~F}) \rightarrow{ }^{3} \mathrm{~T}_{2}(\mathrm{~F})(\mathrm{v} 1),{ }^{3} \mathrm{~A}_{2}(\mathrm{~F}) \rightarrow$ ${ }^{3} \mathrm{~T}_{1}(\mathrm{~F})(\mathrm{v} 2)$ and ${ }^{3} \mathrm{~A}_{2}(\mathrm{~F}) \rightarrow{ }^{3} \mathrm{~T}_{1}(\mathrm{P})(\mathrm{v} 3)$ transitions respec- tively. It suggests tetrahedral geometry of [Ni(TMP) $\left.\left(\mathrm{H}_{2} \mathrm{O}\right)\right] \mathrm{Cl}_{2}$ complex ${ }^{38}$.

\section{ESR spectrum of copper(II) complex}

The ESR spectrum of the $\left[\mathrm{Cu}(\mathrm{TMP})\left(\mathrm{H}_{2} \mathrm{O}\right)_{3}\right] \mathrm{Cl}_{2}$ complex sample was scanned at room temperature (Fig. 5).

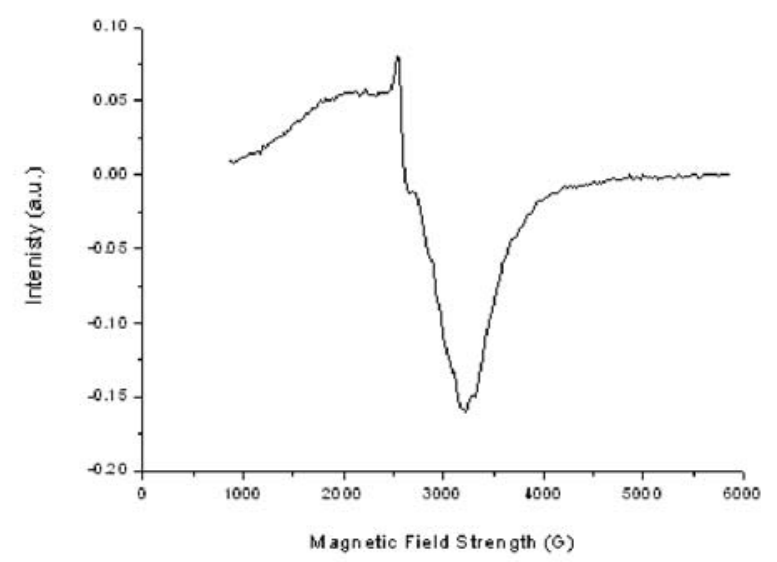

Figure 5. ESR spectrum of copper(II)-TMP complex

The experimental data for the copper(II)-TMP complex are $\mathrm{g}_{||}=2.6831, \mathrm{~g}_{\perp}=2.1321$ and $\mathrm{G}=5.1711$. The anisotropic $G$ values have been calculated by Kneubuhl's method ${ }^{39} . \mathrm{G}=\left(\mathrm{g}_{\mid}-2\right) /\left(\mathrm{g}_{\perp}-2\right)$ which measures the exchange interaction between copper(II) centers. According to Hathaway ${ }^{40}$ if the $G$ value is greater than 4 , the exchange interaction is negligible, while a value of less than 4 indicates a considerable exchange interaction in the complexes. As $\mathrm{G}=5.1711$ for the present complex indicates that there is no spin exchange interaction in the copper complex and hence distorted octahedral geometry proposed for the $\mathrm{Cu}(\mathrm{II})$ complex.

\section{TGA-DTG analyses}

Thermal analysis diagrams (TG/DTG) of the free TMP ligand and its studies copper(II), cobalt(II) and nickel(II)-TMP complexes are represented in Fig. 6. The ligand completely decomposed at $700^{\circ} \mathrm{C}$ with two differential thermogravimetric peaks at $275^{\circ} \mathrm{C}$ and $600^{\circ} \mathrm{C}$, (Figure 6a). From the TG curve, it appears that the sample decomposes in two stages over the temperature range $125-800^{\circ} \mathrm{C}$. The first step occurs at $\left(275^{\circ} \mathrm{C}\right)$ with a mass loss of (obs. $=61 \%$, calc. $=62 \%)$ due to elimination of 1,2,3-trimethoxy-5-methyl-benzene. The second step starts at $375^{\circ} \mathrm{C}$ and ends at $800^{\circ} \mathrm{C}$ with a mass loss (obs. $=39 \%$, calc. $=38 \%)$ attributed to elimination of pyrimidine-2,4-diamine moiety.

The thermal decomposition of the $\left[\mathrm{Cu}(\mathrm{TMP})\left(\mathrm{H}_{2} \mathrm{O}\right)_{3}\right]$ $\mathrm{Cl}_{2}$ complex (Fig. 6b) occurs at three steps. The first degradation step takes place in the range of $75-178^{\circ} \mathrm{C}$ $\left(\mathrm{DTG}_{\max }=132^{\circ} \mathrm{C}\right)$ and it is corresponding to the elimination of two coordinated water molecules due to a weight loss of $8 \%$ in a good match with a theoretical value $7.5 \%$. The second step fall in the range of $178-430^{\circ} \mathrm{C}$ $\left(\mathrm{DTG}_{\max }=325^{\circ} \mathrm{C}\right)$ which is assigned to loss of one water and chlorine gas molecules beside 1,2,3-trimethoxy-5-methyl-benzene moiety with a weight loss $55 \%$ and the calculated value is $65 \%$. The third step fall in the range of $430-800^{\circ} \mathrm{C}\left(\mathrm{DTG}_{\max }=612^{\circ} \mathrm{C}\right)$ which is assigned to loss of pyrimidine-2,4-diamine moiety with a weight loss $22.5 \%$ and the calculated value is $23 \%$. The $\mathrm{CuO}$ 


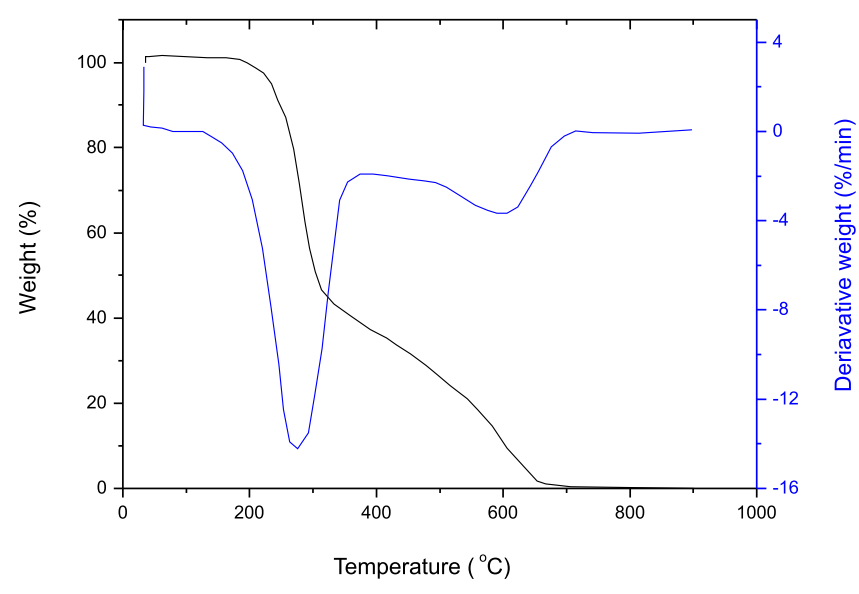

Figure 6a. TG-DTG curves of free TMP

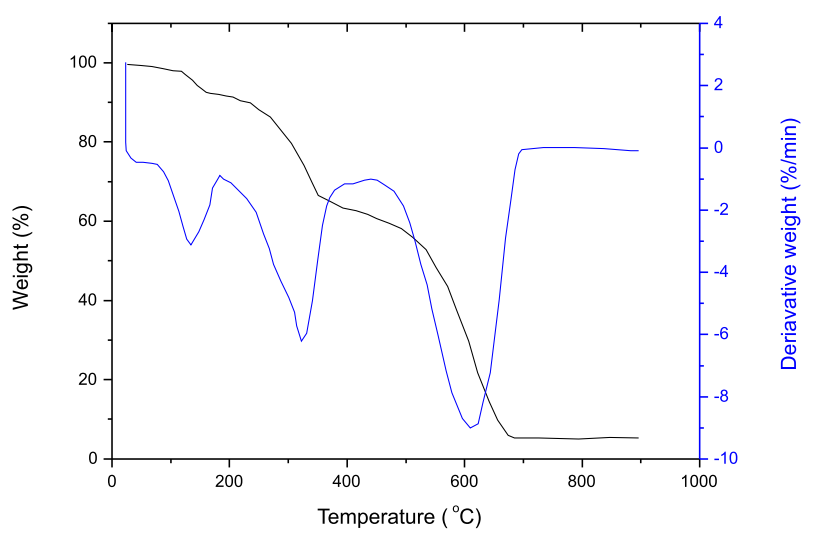

Figure 6b. TG-DTG curves of $\left[\mathrm{Cu}(\mathrm{TMP})\left(\mathrm{H}_{2} \mathrm{O}\right)_{3}\right] \mathrm{Cl}_{2}$ complex

is the final product that remains stable till $800^{\circ} \mathrm{C}$. The thermal decomposition of $\left[\mathrm{Co}(\mathrm{TMP})\left(\mathrm{H}_{2} \mathrm{O}\right)_{3}\right] \mathrm{Cl}_{2}$ complex (Fig. 6c) completely in four steps. The first step ranged at $55-175^{\circ} \mathrm{C}\left(\mathrm{DTG}_{\max }=116^{\circ} \mathrm{C}\right)$ corresponding to the loss of $2 \mathrm{H}_{2} \mathrm{O}$ molecules, representing a weight loss of $7 \%$ and its calculated value is $7.5 \%$. The second and third steps ranged at $175-509^{\circ} \mathrm{C}\left(\mathrm{DTG}_{\max }=280\right.$ \& $473^{\circ} \mathrm{C}$ ) corresponding to the loss of also $\mathrm{H}_{2} \mathrm{O}, \mathrm{Cl}_{2}$ and 1,2,3-trimethoxy-5-methyl-benzene molecules, representing a weight loss of $56 \%$ and its calculated value is $57 \%$. The fourth step occurring at $509-800^{\circ} \mathrm{C}\left(\mathrm{DTG}_{\max }\right.$ $=568^{\circ} \mathrm{C}$ ) corresponding to the loss of pyrimidine-2,4-diamine moiety, representing a weight loss of $23 \%$ and its calculated value is $23 \%$. The $\mathrm{CoO}$ is the final product that remains stable till $800^{\circ} \mathrm{C}$. The $\left[\mathrm{Ni}(\mathrm{TMP})\left(\mathrm{H}_{2} \mathrm{O}\right)\right] \mathrm{Cl}_{2}$ complex decomposed along two decomposition steps (Fig. 6d). The first extended from $152^{\circ} \mathrm{C}$ to $365^{\circ} \mathrm{C}$ (DTGmax $=262^{\circ} \mathrm{C}$ ) and can be assigned to the loss of $\mathrm{H}_{2} \mathrm{O}$ and $\mathrm{Cl}_{2}$ molecules, representing a weight loss of $19 \%$ and its calculated value is $20 \%$. The second step occurring at $365-800^{\circ} \mathrm{C}\left(\mathrm{DTG}_{\max }=545^{\circ} \mathrm{C}\right)$ corresponding to the loss of the 1,2,3-trimethoxy-5-methyl-benzene and other pyrimidine-2,4-diamine moiety moieties, representing a weight loss of $66.5 \%$ and its calculated value is $67 \%$. The final products resulted at $800^{\circ} \mathrm{C}$ contain $\mathrm{NiO}$ oxide.

\section{Kinetic thermodynamic results}

The calculated thermodynamic parameters from TG and DTG are listed in Table 3. The thermodynamic activation parameters of decomposition processes for dehydrated complexes namely activation energy $\left(\Delta \mathrm{E}^{*}\right)$, enthalpy $\left(\Delta \mathrm{H}^{*}\right)$, entropy $\left(\Delta \mathrm{S}^{*}\right)$ and Gibbs free energy change of the decomposition $\left(\Delta \mathrm{G}^{*}\right)$ were evaluated

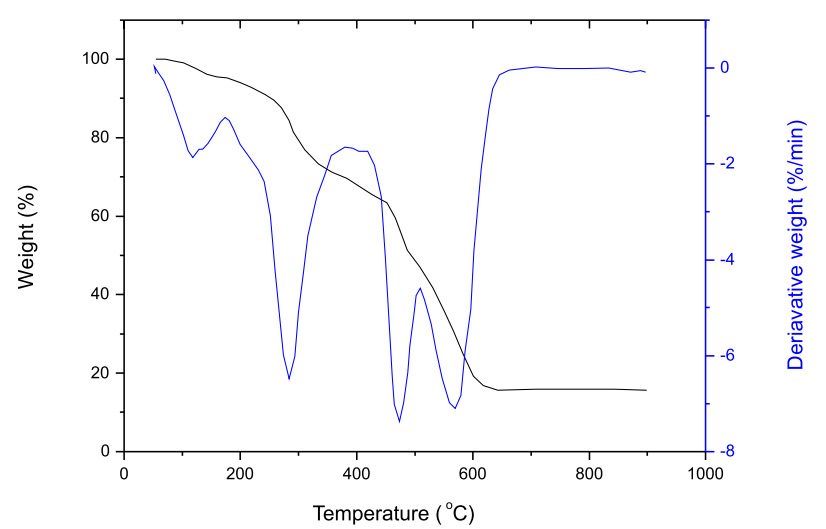

Figure 6c. TG-DTG curves of $\left[\mathrm{Co}(\mathrm{TMP})\left(\mathrm{H}_{2} \mathrm{O}\right)_{3}\right] \mathrm{Cl}_{2}$ complex

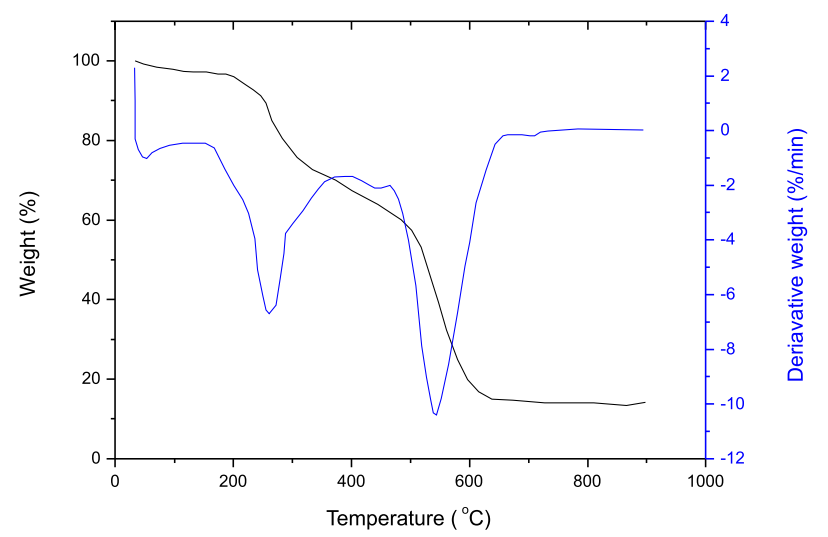

Figure 6d. TG-DTG curves of $\left[\mathrm{Ni}(\mathrm{TMP})\left(\mathrm{H}_{2} \mathrm{O}\right)\right] \mathrm{Cl}_{2}$ complex

graphically by employing the Coats-Redfern and Horowitz - Metzger relations ${ }^{41,42}$. To access the influence of the structural properties of the ligand and the type of the metal on the thermal behavior of the complexes, the order, $n$, and the heat of activation $E$ of the various decomposition stages were determined from the TG and DTG thermograms.

Coats - Redfern equation

The equations as follow:

$\ln \left[\left.\frac{1-(1-\alpha)^{1-n}}{(1-n) T^{2}}\right|^{\prime}=\frac{M}{T}+B \quad\right.$ for $\mathrm{n} \neq 1$

$\left.\ln \left[\frac{-\ln (1-\alpha)}{T^{2}}\right]\right\rfloor=\frac{M}{T}+B \quad$ for $\mathrm{n}=1$

where $M=-E / R$ and $B=\ln A R / \Phi E ; E, R, A$, and $\Phi$ are the heat of activation, the universal gas constant, preexponential factor, and heating rate, respectively. The correlation coefficient, $r$, was computed using the least square method for different values of $n$, by plotting the left-hand side of Eqs. (1) or (2) versus 1000/T.

Horowitz - Metzger equation

The relations derived are as follow:

$\ln [-\ln (1-\alpha)]=\frac{E}{R T_{m}} \Theta$

Where $\alpha$ is the fraction of the sample decomposed at time $\mathrm{t}$ and $\Theta=T-T_{m}$.

A plot of $\ln [-\ln (1-\alpha)]$ against $\Theta$, was found to be linear, from the slope of which $E$, was calculated and $Z$ can be deduced from the relation : 


$$
Z=\frac{E \varphi}{R T_{m}^{2}} \exp \left(\frac{E}{R T_{m}}\right)
$$

Where $\varphi$ is the linear heating rate, the order of reaction, $\mathrm{n}$, can be calculated from the following relationship:

$n=33.64758-182.295 \alpha_{m}+435.9073 \alpha_{m}^{2}-551.157 \alpha_{m}^{3}+$

$+357.3703 \alpha_{m}^{4}-93.4828 \alpha_{m}^{5}$

The $n$ value which gave the best fit $(r \approx 1)$ was chosen as the order parameter for the decomposition stage of interest. From the intercept and linear slope of such stage, the $A$ and $E$ values were determined. The other kinetic parameters, $\Delta H, \Delta S$ and $\Delta G$ were computed using the relationships; $\Delta H=E-R T, \Delta S=R[\ln (A h / k T)-1]$ and $\Delta G=\Delta H-T \Delta S$, where $k$ is the Boltzmann's constant and $h$ is the Planck's constant. The following remarks can be pointed out: (i) all complexes decomposition stages show the best fit for $(n=1)$ indicating a first-order decomposition in all cases. Other $n$ values (e.g. $0,0.33$ and 0.66 ) did not lead to better correlations ${ }^{43}$, 44 ; (ii) the negative values of activation entropies $\Delta S$ indicate a more ordered activated complex than the reactants and/or the reactions are slow ${ }^{45}$; (iii) the positive values of $\Delta H$ mean that the decomposition processes are endothermic.

\section{Transmission electron microscopy}

TEM image (Fig. 7a, 7b, 7c) shows that $\mathrm{Cu}(\mathrm{II})-\mathrm{TMP}$, $\mathrm{Co}(\mathrm{II})-\mathrm{TMP}$ and Ni(II) - TMP complexes nanoparticles are aggregates of irregular shape. The size of [Cu(TMP) $\left.\left(\mathrm{H}_{2} \mathrm{O}\right)_{3}\right] \mathrm{Cl}_{2},\left[\mathrm{Co}(\mathrm{TMP})\left(\mathrm{H}_{2} \mathrm{O}\right)_{3}\right] \mathrm{Cl}_{2}$ and $\left[\mathrm{Ni}(\mathrm{TMP})\left(\mathrm{H}_{2} \mathrm{O}\right)\right]$ $\mathrm{Cl}_{2}$ complexes nanoparticles calculated from TEM images are in the range of 5-20 nm (Fig. 7).

Complexes of trimethoprim with $\mathrm{Cu}(\mathrm{II}), \mathrm{Co}(\mathrm{II})$, and $\mathrm{Ni}(\mathrm{II})$ have been synthesized. Then, these complexes have been characterized by spectroscopic techniques involving UV-vis, FTIR, Raman spectroscopy and ESR. The CHN elemental analysis, molar conductance, magnetic susceptibility, and thermal behavior of complexes have also been investigated. The synthesized TMP behaves as tridentate ligand NNN donor via two nitrogen atoms of amino groups and nitrogen atom of pyrimidine ring. The data of UV-vis spectra and the magnetic measurements recommended that the octahedral geometry for copper(II) and cobalt(II) complexes except for Ni(II) which is tetrahedral was suggested. Furthermore, the kinetic and thermodynamic parameters for the decomposition steps were calculated using the Coats-Redfern and Horowitz-Metzger methods. The morphology of the nanostructured form of the TMP metal complexes has been investigated by transmission electron microscopy (TEM).

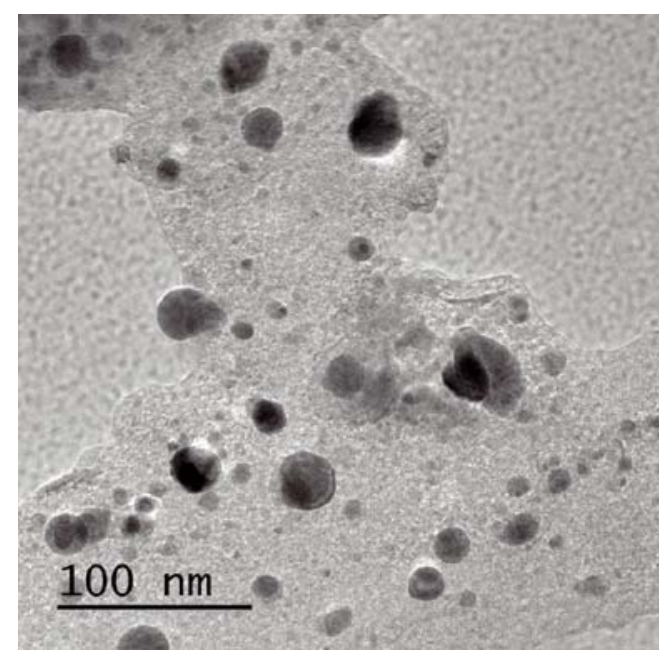

Figure 7a. TEM image of $\left[\mathrm{Cu}(\mathrm{TMP})\left(\mathrm{H}_{2} \mathrm{O}\right)_{3}\right] \mathrm{Cl}_{2}$ complex

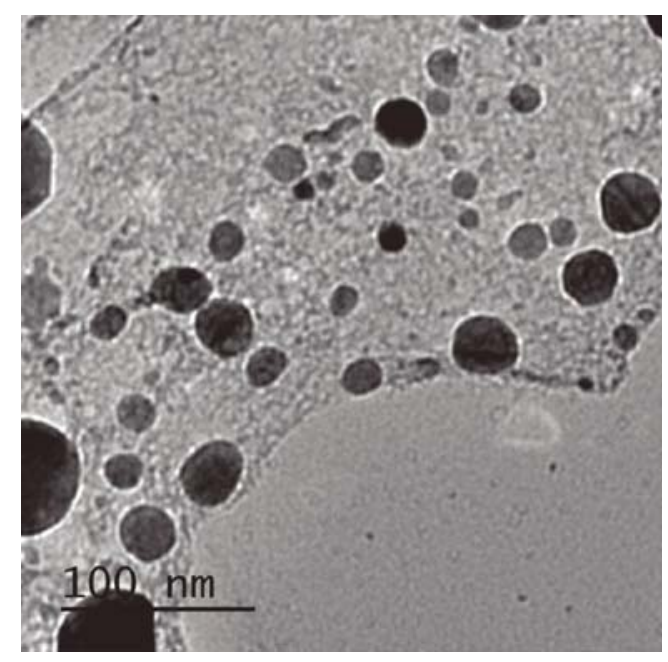

Figure 7b. TEM image of $\left[\mathrm{Co}(\mathrm{TMP})\left(\mathrm{H}_{2} \mathrm{O}\right)_{3}\right] \mathrm{Cl}_{2}$ complex

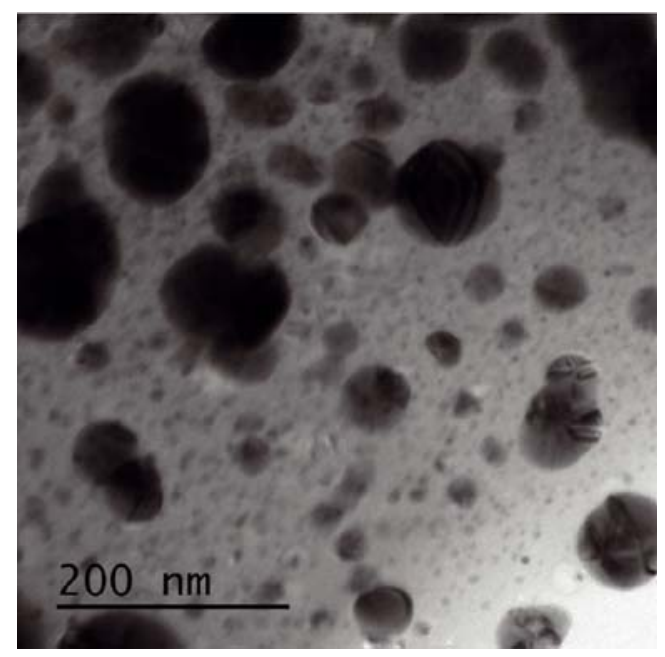

Figure 7c. TEM image of $\left[\mathrm{Ni}(\mathrm{TMP})\left(\mathrm{H}_{2} \mathrm{O}\right)\right] \mathrm{Cl}_{2}$ complex

Table 3. Kinetic parameters of TMP ligand and $\mathrm{Cu}(\mathrm{II}), \mathrm{Co}(\mathrm{II})$ and $\mathrm{Ni}(\mathrm{II})$ complexes

\begin{tabular}{|c|c|c|c|c|c|c|}
\hline \multirow[b]{2}{*}{ Compound } & \multirow[b]{2}{*}{ Methods } & \multicolumn{5}{|c|}{$2^{\text {nd }}$ step } \\
\hline & & $r$ & $\begin{array}{l}\mathrm{E} \\
\left(\mathrm{kJ} \mathrm{mol}^{-1}\right)\end{array}$ & $\begin{array}{c}\Delta \mathrm{S}^{*} \\
\left(\mathrm{~J} \mathrm{k}^{-1} \mathrm{~mol}^{-1}\right)\end{array}$ & $\left(\begin{array}{c}\Delta \mathrm{H}^{*} \\
\left(\mathrm{~mol}^{-1}\right)\end{array}\right.$ & $\begin{array}{c}\Delta \mathrm{G}^{*} \\
\left(\mathrm{~kJ} \mathrm{~mol}^{-1}\right)\end{array}$ \\
\hline \multirow{2}{*}{ TMP } & CR & 0.9933 & $2.88^{*} 10^{4}$ & $-1.43^{*} 10^{2}$ & $2.65^{\star} 10^{4}$ & $1.33^{*} 10^{5}$ \\
\hline & $\mathrm{HM}$ & 0.9946 & $2.92^{*} 10^{4}$ & $-1.37 * 10^{2}$ & $2.71 * 10^{4}$ & $1.41 * 10^{5}$ \\
\hline \multirow{2}{*}{$\mathrm{Cu}(\mathrm{II})$} & $\mathrm{CR}$ & 0.9959 & $1.76 * 10^{4}$ & $-1.23^{*} 10^{2}$ & $1.65^{*} 10^{4}$ & $1.44 * 10^{5}$ \\
\hline & $\mathrm{HM}$ & 0.9912 & $1.70^{*} 10^{4}$ & $-1.30 * 10^{2}$ & $1.61 * 10^{4}$ & $1.37^{*} 10^{5}$ \\
\hline \multirow{2}{*}{$\mathrm{Co}(\mathrm{II})$} & CR & 0.9965 & $1.95^{*} 10^{4}$ & $-1.41 * 10^{2}$ & $1.87^{*} 10^{4}$ & $2.21 * 10^{5}$ \\
\hline & $\mathrm{HM}$ & 0.9954 & $2.10^{*} 10^{4}$ & $-1.32 * 10^{2}$ & $1.69 * 10^{4}$ & $1.99 * 10^{5}$ \\
\hline \multirow{2}{*}{$\mathrm{Ni}(\mathrm{II})$} & CR & 0.9972 & $1.88 * 10^{4}$ & $-1.25^{*} 10^{2}$ & $2.01 * 10^{4}$ & $1.43^{*} 10^{5}$ \\
\hline & $\mathrm{HM}$ & 0.9924 & $1.94^{*} 10^{4}$ & $-1.26 * 10^{2}$ & $1.98 * 10^{4}$ & $1.28 * 10^{5}$ \\
\hline
\end{tabular}




\section{Acknowledgements}

Taif University Researches Supporting Project number (TURSP-2020/01), Taif University, Taif, Saudi Arabia.

\section{LITERATURE CITED}

1. Sharma, R.C., Giri, P.P., Kumar, D. \& Neelam. (2012). Synthesis, spectral and antimicrobial activity of mixed ligand complexes of $\mathrm{Co}(\mathrm{II}), \mathrm{Ni}(\mathrm{II}), \mathrm{Cu}(\mathrm{II})$ and $\mathrm{Zn}(\mathrm{II})$ with $\mathrm{N}, \mathrm{O}$ and S donor ligands. J. Chem. Pharm. Res., 4(4), 1969-1973.

2. Ajibade, P.A. \& Idemudia, O.G. (2013). Synthesis, Characterization, and Antibacterial Studies of $\mathrm{Pd}(\mathrm{II})$ and Pt(II) Complexes of Some Diaminopyrimidine Derivatives. Bioinorg. Chem. Appl., 2013, Article ID 549549, 8 pages. DOI: 10.1155/2013/549549.

3. Demirezen, N., Tarınc, D., Polat, D., Cesme, M., Golcu, A. \& Tumer, M. (2012). Synthesis of trimethoprim metal complexes: Spectral, electrochemical, thermal, DNA-binding and surface morphology studies. Spectrochim. Acta Part A, 94, 243-255. DOI: 10.1016/j.saa.2012.03.055.

4. Ahmed, M.Z. \& Habib, U. (2018). DFT studies of temperature effect on coordination chemistry of $\mathrm{Cu}(\mathrm{II})$ trimethoprim complexes. J. Coord. Chem., 71(8), 1102-1113. DOI: $10.1080 / 00958972.2018 .1447667$.

5. Kovala, D., Hadjiliadis, N. \& Tsangaris, J. (1986). Complexes of 2,4-diamino-5(3',4',5'-trimethovybenvyl)-pyrimidine (trimethoprim) with platinum(II), rhodium(III) and gold(III). J. Less Common Met., 115, 1-8. DOI: 10.1016/0022-5088(86)90365-6.

6. Tsangaris, J., Sotiropoulos, D. \& Galinos, A. (1978). Complexes of trimethoprim with $\mathrm{CuCl}_{2}, \mathrm{NiCl}_{2}$ and $\mathrm{CoCl}_{2}$. Inorg. Nucl. Chem. Lett., 14, 375-380. DOI: 10.1016/00201650(78)80001-4.

7. Demartin, F., Manassero, M., Naldini, L. \& Zoroddu, M. (1983). Metal complexes of 2,4-Diamino-5-3(3',4',5'trimethoxybenzyl)pyrimidine, (trimethoprim). Part I. Synthesis and crystal structure of $\mathrm{CoCl} 2$ (trimethoprim)2. Inorg. Chim. Acta, 77, L213-L214. DOI: 10.1016/S0020-1693(00)82619-5.

8. Naldini, L., Cabras, M., Zoroddu, M., Demartin, F., Manassero, M. \& Sansoni, M. (1984). Metal complexes of 2,4-diamino-5-( $3^{\prime}, 4^{\prime}, 5^{\prime}$-trimethoxybenzyl)pyrimidine, (trimethoprim). Part II. Synthesis, magnetic characterization and $\mathrm{X}$-ray structure of [Cu2(O2CCH3)4(trimethoprim)2]-2C6H6. CH3OH. Inorg. Chim. Acta, 88, 45-50. DOI: 10.1016/S00201693(00)81869-1.

9. Zoroddu, M., Naldini, L., Demartin, F. \& Masciocchi, N. (1987). Metal complexes of 2,4-diamino-5-(3',4',5'trimethoxybenzyl)pyrimidine (trimethoprim) and 2,4-diamino-5-( $p$ chlorophenyl)-6-ethylpyrimidine (pyrimethamine). Part III. Syntheses and $\mathrm{x}$-ray structures of [ $\mathrm{Rh} 2(\mathrm{O} 2 \mathrm{CCH} 3) 4($ trimethoprim $) 2]$ $\cdot 2 \mathrm{C} 6 \mathrm{H} 6 \cdot \mathrm{CH} 3 \mathrm{OH}$ and $[\mathrm{Rh} 2(\mathrm{O} 2 \mathrm{CCH} 3) 4$ (pyrimethamine)2]. Inorg. Chim. Acta, 128, 179-183. DOI: 10.1016/S0020-1693(00)86543-3.

10. Demartin, F., Masciocchi, N., Naldini, L., Panzanelli, A. \& Zoroddu, M. (1990). Metal complexes of 2,4-diamino-5-(3',4',5'trimethoxybenzyl)pyrimidine (trimethoprim) Part IV. Synthesis and $\mathrm{X}$-ray structure of $[\mathrm{CuCl}(\mu-\mathrm{OCH} 3)$ (trimethoprim) $] 2$. Inorg. Chim. Acta, 171, 229-233. DOI: 10.1016/S0020-1693(00)80437-5.

11. Muthiah, P.T. \& Robert, J.J. (1999). Metal-pyrimidine interaction: synthesis and crystal structure of a cadmium complex of trimethoprim ([CdBr2(TMP)2(H2O)2]·H2O, TMP = trimethoprim). J. Chem. Crystallogr., 29, 223-226. DOI: 10.1023/A:1009534513987.

12. Habib, U., Badshah, A., Flörke, U., Qureshi, R.A., Mirza, B., Islam, N. \& Khan, A. (2009). Synthesis and Structural Characterization of (2,4-Diamino-5-(3',4',5'-Trimethoxybenzyl) Pyrimidine Copper (II)) Complex. J. Chem. Crystallogr., 39, 730-734. DOI: 10.1007/s10870-009-9545-9.

13. Habib, U., Badshah, A., Flörke, U., Qureshi, R.A., Mirza, B., Islam, N. \& Khan, A. (2009). Synthesis of (2,4-Diamino5-(3', $4^{\prime}, 5^{\prime}$-trimethoxybenzyl) Pyrimidine) Copper (II) Complex at $20-25^{\circ} \mathrm{C}$ and its Structural Characterization. J. Chem. Crystallogr., 39, 607-611. DOI: 10.1007/s10870-009-9547-7.

14. Simo, B., Perello, L., Ortiz, R., Castineiras, A., Latorre, J. \& Canton, E. (2000). Interactions of metal ions with a 2,4-diaminopyrimidine derivative (trimethoprim): Antibacterial studies. J. Inorg. Biochem., 81, 275-283. DOI: 10.1016/S01620134(00)00118-5.

15. Seekhon, B., Randhawa, H. \& Sahai, H. (1999). On the Coordinating Behaviour of Trimethoprim Towards Some Metal Ions. Synth. React. Inorg. Met.-Org. Chem., 29, 309-321. DOI: 10.1080/00945719909349453.

16. Weder, J.E., Dillon, C.T., Hambley, T.W., Kennedy, B.J., Lay, P.A., Biffin, J.R., Regtop, H.L. \& Davis, N.M. (2002). Copper complexes of non-steroidal anti-inflammatory drugs: an opportunity yet to be realized. Coord. Chem. Rev., 232, 95-126. DOI: 10.1016/S0010-8545(02)00086-3.

17. Ajibade, P.A. \& Kolawole, G.A. (2008). Synthesis, characterization and antiprotozoal studies of some metal complexes of antimalarial drugs. Trans. Met. Chem., 33, 493-497. DOI: 10.1007/s11243-008-9070-2.

18. Clarke, M.J. (2003). Ruthenium metallopharmaceuticals. Coord. Chem. Rev., 236, 207-231. DOI: 10.1016/S00108545(02)00025-5.

19. Ajibade, P.A. \& Kolawole, G.A. (2010). Cobalt(III) Complexes of Some Antimalarial Drugs: Synthesis, Characterization, and in vitro Antiprotozoal Studies. Synth. React. Inorg. Met.Org. Chem., 40, 273-278. DOI: 10.1080/15533171003766691.

20. Ajibade, P.A. \& Kolawole, G.A. (2008). Synthesis, characterization and in vitro antiprotozoal studies of iron(III) complexes of some antimalarial drugs. J. Coord. Chem., 61, 3367-3374. DOI: 10.1080/00958970802072765.

21. Ajibade, P.A., Kolawole, G.A. \& O'Brien, P. (2008). $\mathrm{Co}(\mathrm{II})$ and $\mathrm{Cu}(\mathrm{II})$ complexes of 2,4-diamino-5-(3,4,5-trimethoxybenzyl)pyrimidine. J. Coord. Chem., 61, 328-340. DOI: $10.1080 / 00958970701338770$

22. Lokhande, M.V. (2006). Synthesis and Characterization of Lanthanide (III) Complexes with 2, 4-pyrimidine diamine-5 [(3, 4, 5-trimethoxy phenyl) methyl]. Asian J. Chem., 18, 2662-2668.

23. Ajibade, P.A., Kolawole, G.A. \& O'Brien, P. (2006). Synthesis and characterization of $\mathrm{Ni}(\mathrm{II}), \mathrm{Pd}(\mathrm{II})$ and $\mathrm{Pt}(\mathrm{II})$ complexes of 2,4-diamino-5-(3, 4, 5-trimethoxybenzyl)pyrimidine complexes. J. Coord. Chem., 59, 1621-1628. DOI: $10.1080 / 00958970500537838$.

24. Ibrahim, F.M., Hammza, R.A. \& Fadhil, D.H. (2019). Synthesis and characterization of Trimethoprim metal complexes used as corrosion inhibitors for carbon steel in acid media. Int. J. Corros. Scale Inhib., 8(3), 733-742.

25. Sekhon, B.S., Sahai, H.K. \& Randhawa, H.S. (1998). Complex formation equilibria of 2, 4,-diamino-5 (3', 4'5',-trimethoxybenzyl) pyrimidine,(trimethoprim) with proton and metal ions. Natl. Acad. Sci. Lett., 21, 76-78.

26. Demartin, F., Manassero, M., Naldini, L. \& Zoroddu, M. (1983). Metal complexes of 2,4-Diamino-5-3(3',4',5'trimethoxybenzyl)pyrimidine, (trimethoprim). Part I. Synthesis and crystal structure of $\mathrm{CoCl} 2$ (trimethoprim)2. Inorg. Chim. Acta, 77, L213-L214. DOI: 10.1016/S0020-1693(00)82619-5.

27. Naldini, L., Cabras, M.A., Zoroddu, M.A., Demartin, F., Manassero, M. \& Sansoni, M. (1984). Metal complexes of 2,4-diamino-5-(3',4',5'-trimethoxybenzyl)pyrimidine, (trimethoprim). Part II. Synthesis, magnetic characterization and $\mathrm{X}$-ray structure of [Cu2(O2CCH3)4(trimethoprim)2]-2C6H6. CH3OH. Inorg. Chim. A: Art. Lett., 88, 45-50. DOI: 10.1016/ S0020-1693(00)81869-1.

28. Borowski, A.F. \& Cole-Hamilton, D.J. (1993). Structures and properties of anthranilato- and $\mathrm{N}$-phenylanthranilatorhodium(I) complexes containing triphenylphosphine ligands. Polyhedron, 12, 1757-1765. DOI: 10.1016/S0277-5387(00)84609-4.

29. Fayad, N.K., Al-Noor, T.H. \& Ghanim, F.H. (2012). Synthesis, characterization, and antibacterial activity of mixed 
ligand complexes of some metals with 1-nitroso-2-naphthol and Lphenylalanine. J. Chem. Mat. Res., 2(5), 18-29.

30. Al-Noor, T.H., AL-Jeboori, A.T. \& Aziz, M.R. (2014). Synthesis, characterization and antimicrobial activities of [Fe(II), $\mathrm{Co}(\mathrm{II}), \mathrm{Ni}(\mathrm{II}), \mathrm{Cu}(\mathrm{II})$ and $\mathrm{Zn}(\mathrm{II})]$ mixed ligand complexes schiff base derived from amoxicillin drug and 4-(dimethylamino) benzaldehyde with nicotinamide. J. Chem. Pharm. Res., 6(4), 1225-1231.

31. El-Shekeil, A., Omer, A., Al-Aghbari, S. \& Al-Shuja'a, O. (2013). Anti-Cancer and AntiMicrobial Activity Studies of Some Complexes of Trimethoprim. J. Cancer Res. Updates, 2(1), 14-20.

32. Alaghaz, A.M.A., Farag, R.S., Elnawawy, M.A. \& Ekaw, A.D.A. (2016). Synthesis and Spectral Characterization Studies of New Trimethoprim-Diphenylphosphate Metal Complexes. Int. J. Sci. Res. (IJSR), 5(1), 1220-1229.

33. Deacon, G.B. \& Philips, R.J. (1980). Relationships between the carbon-oxygen stretching frequencies of carboxylato complexes and the type of carboxylate coordination. Coord. Chem. Rev., 33, 227.

34. Lever, A.B.P. (1984). "Inorganic Spectroscopy". $2^{\text {nd }}$ Elsevier Science Publisher, Amsterdam.

35. Liu, H., Wang, H., Gao, F., Niu, D. \& Lu, Z. (2007). Self-assembly of copper(II) complexes with substituted aroylhydrazones and monodentate N-heterocycles: synthesis, structure and properties. J. Coord. Chem., 60(24), 2671. DOI: 10.1080/00958970701302404.

36. Singh, D.P., Kumar, R., Malik, V. \& Tyagi, P. (2007). Synthesis and characterization of complexes of $\mathrm{Co}(\mathrm{II}), \mathrm{Ni}(\mathrm{II})$, $\mathrm{Cu}(\mathrm{II}), \mathrm{Zn}(\mathrm{II})$, and $\mathrm{Cd}(\mathrm{II})$ with macrocycle 3,4,11,12-tetraoxo1,2,5,6,9,10,13,14-octaaza-cyclohexadeca-6,8,14,16-tetraene and their biological screening. Trans. Met. Chem., 32, 1051. DOI: 10.1007/s11243-007-0279-2.

37. Alaghaz, A.M.A. \& Ammar, R.A. (2010). New dimeric cyclodiphosph(V)azane complexes of $\mathrm{Cr}(\mathrm{III}), \mathrm{Co}(\mathrm{II}), \mathrm{Ni}(\mathrm{II})$,
$\mathrm{Cu}(\mathrm{II})$, and $\mathrm{Zn}(\mathrm{II})$ : Preparation, characterization and biological activity studies. Eur. J. Med. Chem., 45, 1314-1322. DOI: 10.1016/j.ejmech.2009.12.008.

38. Alaghaz, A.M.A., Bayoumi, H.A., Ammar, Y.A. \& Aldhlmani, S.A. (2013). Synthesis, characterization, and antipathogenic studies of some transition metal complexes with N,O-chelating Schiff's base ligand incorporating azo and sulfonamide Moieties. J. Mol. Struct., 1035, 383-399. DOI: 10.1016/j.molstruc.2012.11.030.

39. Makode, J.T. \& Aswar, A.S. (2003). Transition metal complexes of bis (s-methyldithiocarbazate) resdiacetophenone. J. Ind. Chem. Soc., 80, 44.

40. Hathaway, B.J. \& Billing, D.E. (1970). The electronic properties and stereochemistry of mono-nuclear complexes of the copper(II) ion. Coord. Chem. Rev., 6, 143. DOI: 10.1016/ S0010-8545(00)80135-6.

41. Coats, A.W. \& Redfern, J.P. (1964). Kinetic parameters from thermogravimetric data. Nature, 201, 68.

42. Horowitz, H.W. \& Metzger, G. (1963). A New Analysis of Thermogravimetric Traces. Anal. Chem., 35, 1464. DOI: 10.1021/ac60203a013.

43. Maravalli, P.B. \& Goudar, T.R. (1999). Thermal and spectral studies of 3- $N$-methyl-morpholino-4-amino-5-mercapto-1,2,4-triazole and 3- $N$-methyl-piperidino-4-amino5-mercapto-1,2,4-triazole complexes of cobalt(II), nickel(II) and copper(II). Thermochim. Acta, 325, 35. DOI: 10.1016/ S0040-6031(98)00548-6.

44. Yusuff, K.K.M. \& Sreekala, R. (1990). Thermal and spectral studies of 1-benzyl-2- phenylbenzimidazole complexes of cobalt(II). Thermochim. Acta, 159, 357. DOI: 10.1016/00406031(90)80121-E.

45. Frost, A.A. \& Pearson, R.G. (1961). Kinetics and Mechanisms, Wiley, New York. 